\title{
ПРОБЛЕМИ ФОРМУВАННЯ В УКРАЇНІ МІНІМАЛЬНИХ ЗАПАСІВ НАФТИ ТА НАФТОПРОДУКТІВ
}

\author{
Чукаєва I. К., д. е. н., г.н.с. \\ Україна, Київ, Державна установа «Інститут економіки та прогнозування НАН Украӥни»
}

DOI: https://doi.org/10.31435/rsglobal_ijite/30082018/6114

\section{ARTICLE INFO}

Received 12 June 2018

Accepted 25 August 2018

Published 30 August 2018

\section{KEYWORDS}

institutional environment, oil and petroleum products, stocks, association with the EU, EU directive. \begin{abstract}
The article analyzes the current state of the institutional environment for the creation of minimum oil and petroleum products reserves in accordance with the documents of the Association of Ukraine with the EU. In particular, the problems and prospects of the implementation of the plan of implementation of the European Directive 2009/119 / EU concerning the formation of stabilization oil and oil products, in which the draft model for the creation of oil and petroleum products reserves is presented.
\end{abstract}

Citation: Чукаєва I. К. (2018) Problemy Formuvannia v Ukraini Minimalnykh Zapasiv Nafty ta Naftoproduktiv. International Journal of Innovative Technologies in Economy. 7(19). doi: 10.31435/rsglobal_ijite/30082018/6114

Copyright: (C) 2018 Чукаєва I. К. This is an open-access article distributed under the terms of the Creative Commons Attribution License (CC BY). The use, distribution or reproduction in other forums is permitted, provided the original author(s) or licensor are credited and that the original publication in this journal is cited, in accordance with accepted academic practice. No use, distribution or reproduction is permitted which does not comply with these terms.

Вступ. Підписуючи в 2014 році документи по асоціації з ЄС, Україна взяла на себе зобов'язання по створенню мінімальних запасів нафти і нафтопродуктів (МЗНН). До цього іï зобов'язують договір про заснування Енергетичного Співтовариства, який є частиною політики Євросоюзу стосовно експортного законодавства і директива 2009/119/ЄС. У відповідність з цими документами, всі країни СС, і Україна в тому числі, повинні сформувати МЗНН до 2023 року.

Орієнтовна вартість підготовки інфраструктури для МЗНН становить приблизно 200 млн. грн. на рік, 500 млн. грн. в рік йде на формування самого стратегічного запасу, і ще 300 млн. грн припадає на зберігання і оновлення резерву.

Наші сусіди, Угорщина і Румунія, витратили на створення своїх паливних запасів 4 і 5 років.

Результати дослідження. Україна вже 15 років намагається сформувати свої мінімальні запаси нафти та нафтопродуктів. Зокрема, Меморандум між Україною та Європейським Союзом про порозуміння щодо співробітництва в енергетичній галузі від 01.12.2005 p. передбачає положення про надання допомоги Україні в реалізації іiі національної стратегії безпеки поставок нафти.

Відзначається, що сторони зобов'язуються розпочати спільну роботу з метою розробки системи управління українськими стратегічними запасами нафти з урахуванням практики $\mathrm{CC}$ (підпункт «h» п.3.4) [1].

3 метою реалізації положень зазначеного Меморандуму Розпорядженням Кабінету Міністрів України від 08.12.2009 р. було затверджено Концепцію створення в Україні мінімальних запасів нафти і нафтопродуктів на період до 2020 року [2].

Досягнення зазначеної мети передбачає створення мінімальних запасів, що з урахуванням обсягу власного видобутку нафти гарантує наявність 90-денного обсягу внутрішнього споживання нафти і нафтопродуктів відповідно до стандартів СС, визначених Директивами Ради 68/414/ЄЕС від 
20.12.1968 р., 98/93/СС від 14.12.1998 р., 2006/67/СС від 24.07.2006 р., 2009/119/ЄС від 14.09.2009 р. щодо зобов'язань держав - членів ЄС підтримувати мінімальні запаси сирої нафти i/aбо нафтопродуктів та забезпечувати їх зберігання, оновлення та використання.

Зокрема, ч.1 ст.3 Директиви Ради 2009/119/ЄС від 14.09.2009 р. встановлює, що державичлени приймають належні закони, підзаконні акти та адміністративні положення для забезпечення збереження на їх користь на території Співтовариства та на постійних засадах загального рівня резервів нафти, який був би еквівалентним 90 днями середньодобового значення імпорту нетто, або шістдесят одним днем середнього внутрішнього добового споживання [3 ].

17 травня 2016 року голова Державного агентства резерву України Вадим Мосійчук повідомив про підготовку плану імплементації Європейської директиви 2009/119/ЄС щодо формування стабілізаційного запасу нафти і нафтопродуктів [4].

Метою розробки плану імплементації було розв'язання проблем довкола створення в Україні системи мінімальних запасів нафти та нафтопродуктів та управління нею, яка б діяла відповідно до Директиви 2009/119/СС стосовно накладання на держав-членів СС зобов'язання щодо підтримки мінімальних запасів нафти та/або нафтопродуктів.

План імплементації Директиви Ради СС 2009/119/ЄС стосовно покладення на державчленів СС зобов'язання щодо підтримки мінімальних запасів сирої нафти та/або нафтопродуктів від 14 вересня 2009 року було підготовлено на виконання:

статті 338 Угоди про асоціацію між Україною, з однієї сторони, та Європейським Союзом, Європейським Співтовариством 3 атомної енергії і їх державами-членами, 3 іншої сторони (строк імплементації положень Директиви у законодавство України - протягом 3 років 3 дати набрання чинності цією Угодою, строк впровадження - протягом 11 років 3 дати набрання чинності цією Угодою);

пункту 181 Плану заходів з імплементації Угоди про асоціацію між Україною, з однієї сторони, та Європейським Союзом, Європейським Співтовариством з атомної енергії і їх державами-членами, 3 іншої сторони на 2014-2017 роки, затвердженого розпорядженням Кабінету Міністрів України від 17 вересня 2014 року № 847 «Про імплементацію Угоди про асоціацію між Україною, 3 однієї сторони, та Європейським Союзом, Європейським Співтовариством 3 атомної енергії і їхніми державами-членами, 3 іншої сторони» (строк виконання відповідно до Плану заходів - липень 2015 року).

Положення Угоди про асоціацію підпадають під тимчасове застосування відповідно до статті 486 Угоди та Вербальної ноти Генерального секретаріату Ради Європейського Союзу від 30 вересня 2014 року щодо тимчасового застосування положень Угоди про асоціацію

Відповідальним за організацію роботи та виконання заходів плану імплементації було визначено Міненерговугілля у межах своїх повноважень відповідно до Указу Президента від 6 квітня 2011 року № 382 «Про Положення про Міністерство енергетики та вугільної промисловості України». Співвиконавці: Мінекономрозвитку, Мінфін, НАК «Нафтогаз України» (за згодою), інші центральні органи виконавчої влади.

Відповідно до Положення про Міністерство економічного розвитку і торгівлі України, затвердженого постановою Кабінету Міністрів України від 20 серпня 2014 року № 459 «Питання Міністерства економічного розвитку і торгівлі» Мінекономрозвитку є головним органом у системі центральних органів виконавчої влади, що забезпечує формування та реалізує державну політику, зокрема економічного розвитку. Мінекономрозвитку має бути залученим до процесу розробки нормативно-правових актів 3 питань, врегульованих Директивою 2009/119/СС.

Відповідно до Положення про Міністерство юстиції України, затвердженого постановою Кабінету Міністрів України від 2 липня 2014 року № 228, Мін'юст відповідно до покладених на нього завдань, зокрема, здійснює науково-експертне, аналітичне, інформаційне та методологічне забезпечення виконання Загальнодержавної програми адаптації законодавства України до законодавства Свропейського Союзу, переклад актів acquis communautaire українською мовою, оновлення глосарія термінів асquis communautaire.

На першому етапі створення мінімальних запасів нафти та нафтопродуктів $є$ затвердження Урядом України моделі запасів нафти та нафтопродуктів, яка містить план поступового нарощування запасів сирої нафти і нафтопродуктів, програму фінансування, інформацію про відповідальний орган, а також кроки з апроксимації законодавства щодо запасів нафти і нафтопродуктів.

Таке рішення необхідно затвердити у координації з Секретаріатом Енергетичного Співтовариства та з метою виконання положень Директиви 2009/119/СС. 
На другому етапі створення мінімальних запасів нафти та нафтопродуктів є схвалення проекту закону про запаси нафти і нафтопродуктів після погодження його із Секретаріатом Енергетичного Співтовариства.

Основним програмним документом у сфері створення мінімальних запасів нафти та нафтопродуктів є Енергетична стратегія України на період до 2030 року.

Основними нормативно-правовими актами, які регулюють правовідносини у цій сфері є:

Кодекс України про надра;

Закон України «Про нафту і газ»;

Закон України «Про трубопровідний транспорт»;

розпорядження Кабінету Міністрів України від 8 грудня 2009 року № 1498 «Про схвалення Концепції створення в Україні мінімальних запасів нафти та нафтопродуктів на період до 2020 року».

Необхідно підкреслити, що на сьогоднішній день ситуація на ринку нафтопереробки України така, що швидко, якісно і без зайвих витрат переробити нафту в кінцевий продукт не вийде.

В Україні працює лише один нафтопереробний завод - Кременчуцький НПЗ. Створювати запаси нафти, з огляду на, що переробляти iї можна на одному лише НПЗ невиправданий ризик.

Відповідно до плану імплементації Європейської директиви 2009/119/СС щодо формування стабілізаційного запасу нафти і нафтопродуктів Державне агентство резерву України 26.07.2018 p. презентувало перший варіант законопроекту про мінімальні запаси нафти і нафтопродуктів.

В рамках презентації була представлена модель створення запасів нафти i нафтопродуктів згідно з якою, структура мінімальних запасів нафти і нафтопродуктів (МЗНH), виходячи 3 фактичної потужності українських НПЗ, буде складатися 3 30\% нафти і $70 \%$ нафтопродуктів; нафтопродукти повинні включати автомобільний бензин і дизельне паливо

Для управління мінімальними запасами нафти і нафтопродуктів (МЗНН) буде створено незалежне агентство, 70\% власності якого буде у держави, 30\% - у операторів ринку.

Для зменшення операційних витрат, рекомендується використовувати систему stocktickets, яка дозволяє зберігати і використовувати потужності зберігання в сусідніх державах на основі міжнародних угод; інші витрати повинні фінансуватися з акцизного податку.

Щоб забезпечити мінімальні запаси нафти $\mathrm{i}$ нафтопродуктів, Україні потрібно накопичити мінімальні запаси нафти і нафтопродуктів в обсязі понад 2 млн тонн еквівалента сирої нафти (580 тисяч тонн нафти, 460 тисяч тонн бензинів і 930 тисяч тонн дизельного палива) до кінця 2022 року.

Для накопичення цього ресурсу, за оцінками Енергетичного співтовариства, знадобиться 1,084 мільярда доларів. Ці гроші будуть необхідні для оплати закупівлі палива, а потім - для оплати його зберігання.

Нафта і нафтопродукти будуть зберігається на комбінатах, які підвідомчі Держрезерву. Для створення і управління резервом планується створити окреме держпідприємство "Нафторезерв".

Існує два можливих варіанти фінансування такого резерву: перший - це поетапне підвищення акцизу на нафтопродукти (щорічно в середньому на 35-42 копійок за літр нафтопродукту протягом 2017-2022 років і на 8 копійок за літр в 2023 році), а другий - це кредитні кошти від Світового банку, Свропейського банку реконструкції та розвитку або інших міжнародних фінансових організацій.

На думку фахівців, в запропонованому проекті моделі є ряд недоліків.

1. У проекті моделі МЗНН необхідно чітко визначити джерело фінансування створення i функціонування запасів, а саме - фіксована частка акцизного податку з усього обсягу нафтопродуктів реалізується на внутрішньому ринку країни, яка буде направлятися для МЗНН.

Крім того, як заявили учасники Нафтогазовій Асоціації України, будучи представниками бізнесу, за умови вибору акцизу, як джерела фінансування, вони готові підтримати створення мінімального запасу нафти і нафтопродуктів, в тому числі, надавши на ринкових умовах свою інфраструктуру і взявши на себе реалізацію частини завдань.

2. Закупівля нафти і нафтопродуктів для запасів повинна здійснюється на формульній основі 3 прив'язкою до котирувань світових агентств 3 можливим використанням фінансування через довгострокові позики від міжнародних фінансових організацій на пропорційній основі (держава й учасники ринку), вартість їх зберігання, оновлення та реалізація формується на ринкових умовах.

3. Проект постанови «Про затвердження моделі формування мінімальних запасів нафти і нафтопродуктів в Україні» необхідно виносити на розгляд Державної регуляторної служби. 
Висновки. Створення мінімальних запасів нафти та нафтопродуктів, виключно державою чи спільно 3 нафтовими компаніями, визнається однією 3 форм державного регулювання ринку енергоресурсів.

Адже цілком раціональним є висновок про те, що суб’єкти господарювання, які торгують нафтою та нафтопродуктами, отримуючи від цього прибуток, повинні нести відповідальність перед своїми клієнтами та убезпечувати їх від ризиків, оплачуючи створення мінімальних резервів.

Такий підхід цілком відповідає сучасній концепції соціальної відповідальності бізнесу, який має бути враховано під час формування вітчизняної моделі створення мінімальних запасів нафти та нафтопродуктів.

\section{ЛIТЕРАТУРА}

1. Меморандум між Україною та Європейським Союзом про порозуміння щодо співробітництва в енергетичній галузі від 1 грудня 2005 року // Офіційний вісник України. - 2006. - № 13. - Ст. 945.

2. Розпорядження Кабінету Міністрів України «Про схвалення Концепції створення в Україні мінімальних запасів нафти і нафтопродуктів на період до 2020 року» : від 08.12.2009 p., № 1498-p // Офіційний вісник України. - 2009. - № 96. - Ст. 3316.

3. Директива 2009/119/ЄС Ради від 14 вересня 2009 р. стосовно накладення на державчленів СС зобов'язання щодо підтримки мінімальних запасів сирої нафти та/або нафтопродуктів [Електронний pecypc]. - Режим доступу: http://old.minjust.gov.ua/file/32530.

4. План імплементації Директиви Ради ЄС 2009/119/СС стосовно покладення на держав-членів СС зобов'язання щодо підтримки мінімальних запасів сирої нафти та/або нафтопродуктів від 14 вересня 2009 року //Офіційний вісник ЄC L 265, 9 жовтня 2009 р., с. 9-23. 